Check for updates

Cite this: RSC Adv., 2017, 7, 30086

\title{
Preparation of up-converting nano-biphasic calcium phosphate
}

Received 28th April 2017 Accepted 6th June 2017

DOI: $10.1039 / c 7 r a 04809 b$

rsc.li/rsc-advances

\author{
Paulina Sobierajska, (D) ${ }^{a}$ Katarzyna Zawisza, ${ }^{a}$ Robert M. Kowalski, (D) a \\ Guillaume Renaudin, (D) ${ }^{\mathrm{b}}$ Jean-Marie Nedelec, (1D ${ }^{\mathrm{b}}$ Jan Zienkiewicz ${ }^{\mathrm{a}}$ \\ and Rafal J. Wiglusz (D)*a
}

The nano-biphasic calcium phosphate co-doped with $1 \mathrm{~mol} \% \mathrm{Er}^{3+}$ and $5 \mathrm{~mol} \% \mathrm{Yb}^{3+}$ ions was prepared using Pechini's technique. The preparation of the biphasic calcium phosphate showed the removal of fluorine ions from the matrix. The structural properties and morphology of the particles were studied by means of XRD (X-ray powder diffraction), TEM (Transmission Electron Microscopy), and SEM (Scanning Electron Microscopy) techniques. The spectroscopic properties of $\mathrm{Ca}_{10}\left(\mathrm{PO}_{4}\right)_{6} \mathrm{~F}_{2} / \mathrm{Ca}_{3}\left(\mathrm{PO}_{4}\right)_{2}: \mathrm{Er}^{3+}, \mathrm{Yb}^{3+}$ nano-biphasic calcium phosphate were investigated in detail using emission spectra, power dependence and emission kinetics. This material demonstrated intense green up-conversion depending on laser power. Additionally, the luminescence lifetimes for $\mathrm{Er}^{3+}$ ions were calculated from the measured decays. Power dependence of the green and red emissions was found to result from a temperature increase of nano-biphasic calcium phosphate that opens potential applications in theranostics.

\section{Introduction}

Nowadays, calcium phosphates are the most important biomaterials applied in bone tissue engineering due to their chemical compatibility and their affinity to the mineral constituents of human hard tissue. ${ }^{1-3}$ Among them, hydroxyapatite $\left(\mathrm{Ca}_{10}\left(\mathrm{PO}_{4}\right)_{6}(\mathrm{OH})_{2}\right.$ - hereafter $\left.\mathrm{HAp}\right)$ and $\beta$-tricalcium diphosphate $\left(\beta-\mathrm{Ca}_{3}\left(\mathrm{PO}_{4}\right)_{2}\right.$ - hereafter $\beta$-TCP) are the most widely used. ${ }^{4}$ Nevertheless, there is a remaining interest in improvement of their properties in order to achieve a better biological response. One of the methods consists of embedding some additives into the apatite structure, another involves the use of biphasic calcium phosphates containing both compounds - for instance HAp and $\beta$-TCP.

Presently, fluorine ions $\left(\mathrm{F}^{-}\right)$are the most frequently used supplement in hydroxyapatite, which improves its physicochemical properties such as solubility, thermal stability, crystallinity and resistance to acid corrosion. ${ }^{5-8}$ Furthermore, it enhances bone growth, osseointegration and mineralization., ${ }^{\mathbf{9}, 10}$ The $\mathrm{F}^{-}$ion is a microelement present in human enamel and possesses inhibiting properties to bacterial metabolism. ${ }^{\mathbf{1 1 - 1 3}}$ Due to the absence of $\mathrm{OH}^{-}$ions that are luminescence quenching centers, fluorapatite lattice is expected to be a more suitable matrix for luminescence applications. ${ }^{\mathbf{1 4}}$ The fluorine ion is smaller $(1.28 \AA$ ) compared to the hydroxyl ion $(1.37 \AA)$, so

anstitute of Low Temperature and Structure Research, PAS, Okolna 2, 50-422 Wroclaw, Poland. E-mail: R.Wiglusz@int.pan.wroc.pl; Fax: +48071 3441029; Tel: +480713954159

${ }^{b}$ Université Clermont Auvergne, CNRS, SIGMA Clermont, ICCF, F-63000 ClermontFerrand, France
$\mathrm{F}^{-}$ions can fill more closely the unit cell resulting in smaller cell volume. $^{15}$

The fluorapatite $\left(\mathrm{Ca}_{10}\left(\mathrm{PO}_{4}\right)_{6} \mathrm{~F}_{2}\right.$ - hereafter FAp) crystallizes in hexagonal space group $\mathrm{PG}_{3} / \mathrm{m}$ and contains ten calcium cations located in two nonequivalent sites - four $\mathrm{Ca}(1)$ ions with threefold $C_{3}$ symmetry surrounded by nine oxygen atoms, and six $\mathrm{Ca}(2)$ ions with $C_{\mathrm{s}}$ symmetry coordinated by six oxygen atoms and one fluoride atom. Rare earth ions could substitute calcium in both sites. ${ }^{16}$ This compound has been used as a host lattice for luminescent ions such as europium, ${ }^{\mathbf{1 6}}$ neodymium, ${ }^{\mathbf{1 7}}$ praseodymium, ${ }^{18}$ co-doped by ytterbium and holmium ${ }^{19}$ amongst others. It is well known that fluorine ions release from lattice during material thermal treatment, especially when material is highly carbonated. ${ }^{\mathbf{2 0 , 2 1}}$

The $\beta$-TCP crystallizes in the rhombohedral space group $R \overline{3} c$ and it is isostructural to the natural mineral whitlockite: $\mathrm{Ca}_{18.19} \mathrm{Mg}_{1.17} \mathrm{H}_{1.62}\left(\mathrm{PO}_{4}\right)_{14}$. The calcium ions are present in five different crystallographic sites. Four sites $\mathrm{Ca}(1), \mathrm{Ca}(2), \mathrm{Ca}(3)$ and $\mathrm{Ca}(5)$ are wholly occupied, but the $\mathrm{Ca}(4)$ position is half occupied in a statistical way. The $\mathrm{Ca}(1), \mathrm{Ca}(2), \mathrm{Ca}(3)$ and $\mathrm{Ca}(5)$ are coordinated respectively with seven, eight, eight, and six oxygen atoms. $\mathrm{Ca}(4)$ is threefold coordinated implying weak bonding and the formation of vacancy. ${ }^{22,23}$ The solubility activity product of $\beta$-TCP is higher than hydroxyapatite causing faster bone growth and integration with bone tissue. ${ }^{24,25}$ The advantageous role of the $\beta-\mathrm{Ca}_{3}\left(\mathrm{PO}_{4}\right)_{2}$ is related to facilitate the boneformation on their surface by influence of the processes connected with attaching, proliferation as well as migration of the bone cells. ${ }^{26}$ Therefore, the enhancement of biodegradation relies on the preparation of mixtures or composites containing 
both phases of phosphates. There are some studies concerning $\beta$-TCP co-doped with lanthanides ions (the $\beta$-TCP: $\mathrm{Er}^{3+} / \mathrm{Yb}^{3+}$ ) that consider the in vivo bioimaging under IR excitation (upconversion process $)^{27}$ as well as doped with $\mathrm{Eu}^{3+28}$ and $\mathrm{Eu}^{2+29}$ ions for light industry applications amongst others. ${ }^{25,30-32}$

The most of the bio-applications require nanosized materials, but the number of current studies on luminescent apatite nanoparticles is very limited. Calcium phosphates doped with luminescent ions are studied as inorganic labels aimed at fluorescence imaging, which is one of the most important techniques used in diagnostic applications. ${ }^{19,33}$ The doped and co-doped apatites, in comparison with fluorescence organic labels, are more resistant to aggressive factors such as photodegradation, high temperature, or oxidation process, the emission are characterized by narrow and intense bands, high fluorescence quantum yield, long decay times, therefore these materials are promising for bio-detection applications. The excitation by NIR radiation lead to deeper tissue penetration due to "the optical transparency window" of biological tissue (700-1100 nm). ${ }^{19,33}$ The up-converting nanoparticles (UCNP) are the most important material devoted to this purpose owing to their excitation at NIR range of electromagnetic radiation. In the up-conversion process, two or more low-energy photons (in NIR range) are converted into a high-energy photon (in UV-VIS region), which is founded on sequential absorption and energy transfer between doping ions $\left(\right.$ e.g. $\left.\mathrm{Er}^{3+} / \mathrm{Yb}^{3+}\right){ }^{34,35}$

In the paper, there is presented the results concerning biphasic calcium phosphate of fluorapatite (FAp) and $\beta$-tricalcium phosphate ( $\beta$-TCP) co-doped with $\mathrm{Er}^{3+}$ and $\mathrm{Yb}^{3+}$ ions obtained using the sol-gel synthesis. First of all, it is very important aspect of biomaterial preparation, in the case of the biphasic materials, to obtain the difference of solubility between them ( $\beta$-TCP being far more soluble than FAp). The mixture of the two compounds known as the Biphasic Calcium Phosphate (BCP) are highly desirable for bone substitutes and bone cement applications. Mixing of both phosphates contributes to better cellular response to the applied material due to better integration with a tissue. ${ }^{36,37}$

Secondly, upconversion luminescent nanoparticles (UCNP) with the anti-Stokes emission have been paid attention in the field of biomedicine as theranostic agents. ${ }^{38}$ The emission and excitation of UCNPs is located in the optical window of biological tissue what minimize the overheating effect from the excitation irradiation at $980 \mathrm{~nm}$ the biological markers. ${ }^{39}$

Therefore, the aim of proposed research was to obtain the bioactive materials with controlled biodegradability, intended for the future theranostic applications, especially within the cranial and facial bones.

\section{Experimental procedure}

\subsection{Materials and synthesis}

The nanocrystalline $\mathrm{Ca}_{10}\left(\mathrm{PO}_{4}\right)_{6} \mathrm{~F}_{2} / \mathrm{Ca}_{3}\left(\mathrm{PO}_{4}\right)_{2}$ biphasic calcium phosphate co-doped with $\mathrm{Er}^{3+}$ and $\mathrm{Yb}^{3+}$ ions were prepared by modified Pechini's method using $9.4 \mathrm{mmol}$ of $\mathrm{Ca}\left(\mathrm{NO}_{3}\right)_{2} \cdot 4 \mathrm{H}_{2} \mathrm{O}$ ( $\geq 99 \%$ Acros organics), $0.05 \mathrm{mmol}$ of $\mathrm{Er}_{2} \mathrm{O}_{3}$ (99.99\% Alfa Aesar), $0.25 \mathrm{mmol}$ of $\mathrm{Yb}_{2} \mathrm{O}_{3}$ (99.99\% Alfa Aesar), $6 \mathrm{mmol}$ of $\left(\mathrm{NH}_{4}\right)_{2} \mathrm{HPO}_{4}$
( $\geq 98 \%$ Avantor Performance Materials) and $2 \mathrm{mmol}$ of $\mathrm{NH}_{4} \mathrm{~F}$ (98\% Alfa Aesar). Concentration of $\mathrm{Er}^{3+}$ and $\mathrm{Yb}^{3+}$ ions have been set to $1 \mathrm{~mol} \%$ and $5 \mathrm{~mol} \%$ respectively, in replacement of overall molar content of $\mathrm{Ca}^{2+}$ ions. In this method, stoichiometric amounts of $\mathrm{RE}^{3+}$ oxides were taken and digested in excess of $\mathrm{HNO}_{3}$ (ultrapure Avantor) in order to transform them into water soluble nitrates and eventually purified by triple recrystallization. Subsequently, calcium nitrate was dissolved in deionized water together with erbium(III) and ytterbium(III) nitrates. Afterwards, the excess (12.5-fold relative to the total amount of cations) of citric acid (99.5\% Sigma Aldrich) as well as ethylene glycol (ultrapure Avantor) were added under constant stirring at $60{ }^{\circ} \mathrm{C}$ resulting in a viscous mixture. Finally, suitable amounts of ammonium hydrogen phosphate and ammonium fluoride were added to the mixture resulting in a turbid precipitation of the by-product. The mixture was further dried for 5 days at $90{ }^{\circ} \mathrm{C}$. Afterwards, the gel thus obtained was thermally treated in the temperature range 700$1000{ }^{\circ} \mathrm{C}$. Only the sample annealed at $1000{ }^{\circ} \mathrm{C}$ enabled us to obtain the pure phase biphasic calcium phosphate, with no extraneous phases. Therefore, the sample calcined at $1000{ }^{\circ} \mathrm{C}$ was selected for the spectroscopic studies.

The modified Pechini's method combines the advantages of sol-gel as well as thermal decomposition techniques. Such method requires using organic substrates such ethylene glycol and citric acid forming polymer-metal ions resins. The modified Pechini's method offers a chemically homogeneous product with high purity. However, in the case of calcium phosphates the high annealing temperature about $700{ }^{\circ} \mathrm{C}$, in order to remove any organic components, is the reason to obtain the multiphasic materials.

\subsection{Material characterization}

Powder diffraction studies were carried out using PANalytical X'Pert Pro diffractometer equipped with Ni-filtered $\mathrm{Cu} \mathrm{K} \alpha$ radiation $(V=40 \mathrm{kV}, I=30 \mathrm{~mA})$. The microstructure investigations and elemental analysis were carried out using a scanning electron microscope FEI Nova NanoSEM 230 equipped with EDS spectrometer (EDAX PegasusXM4). Up to 10 measurements were made from different random areas for each sample. In order to check the particle size and morphology the HRTEM using a Philips CM-20 Super Twin microscope, operated at $200 \mathrm{kV}$, with the resolution of $0.24 \mathrm{~nm}$, was performed. The samples were deposited on a $\mathrm{Cu}$ grid with a carbon film from a suspension in ethanol. Afterwards a droplet of suspension was deposited on a copper microscope grid covered with perforated carbon. The primary size of particles was evaluated using volume weighted formula:

$$
d_{\mathrm{av}}=\frac{\sum n_{\mathrm{i}} d_{\mathrm{i}}{ }^{4}}{\sum n_{\mathrm{i}} d_{\mathrm{i}}{ }^{3}},
$$

where $d_{\mathrm{av}}$ is the average particle size, $n$ number of particles and $d$ represents particle diameter.

The emission was observed using a set-up consisting of a grating spectrograph Princeton Instrument Acton SP2500 and a streak camera Hamamatsu C5680. The power dependence of 
the up-conversion emission intensity was measured using a laser diode Apollo Instruments F4-980-6 emitting continuous $980 \mathrm{~nm}$ line on powders. The data were fitted according to the following formula:

$$
I_{\mathrm{UPC}}=I_{\mathrm{in}}{ }^{N}
$$

$N$ showing the number of photons required for anti-Stokes emission. Luminescence decay curves were excited with a Continuum Surelite I optical parametric oscillator (OPO) pumped by a third harmonic of Nd:YAG laser and recorded with a Tektronix Model MDO 4054b-3 digital oscilloscope.

\section{Results and discussion}

\subsection{Structural and morphological analysis}

The crystal structures were characterized by XRD as a function of annealing temperature in the $700-1000{ }^{\circ} \mathrm{C}$ range (see Fig. 1). First of all, the temperature regime started at $700{ }^{\circ} \mathrm{C}$ in order to get rid of carbon content under heat-treating conditions. Such problems could be overcome through the sintering process time but the increase of the annealing time causes particle growth. Secondly, it is well known that above $1000{ }^{\circ} \mathrm{C}$ the $\beta$-TCP transforms into the high temperature $\alpha$-TCP phase, therefore higher preparation does not make sense. Moreover, the removal of fluorine ions in the presence of $\mathrm{NH}_{4}{ }^{+}$ions and high temperature occurs as follows:

$$
\mathrm{NH}_{4}^{+}+\mathrm{F}^{-} \rightarrow \mathrm{NH}_{4} \mathrm{~F} \uparrow
$$

The obtained powders were ascribed to the FAp crystallizing in the hexagonal structure with space group $P 6_{3} / m$ (ICSD 9444) and to rhombohedral $\beta$-TCP with $R \overline{3} c$ (ICSD 97500), respectively. Over the entire temperature range, phase decomposition of the

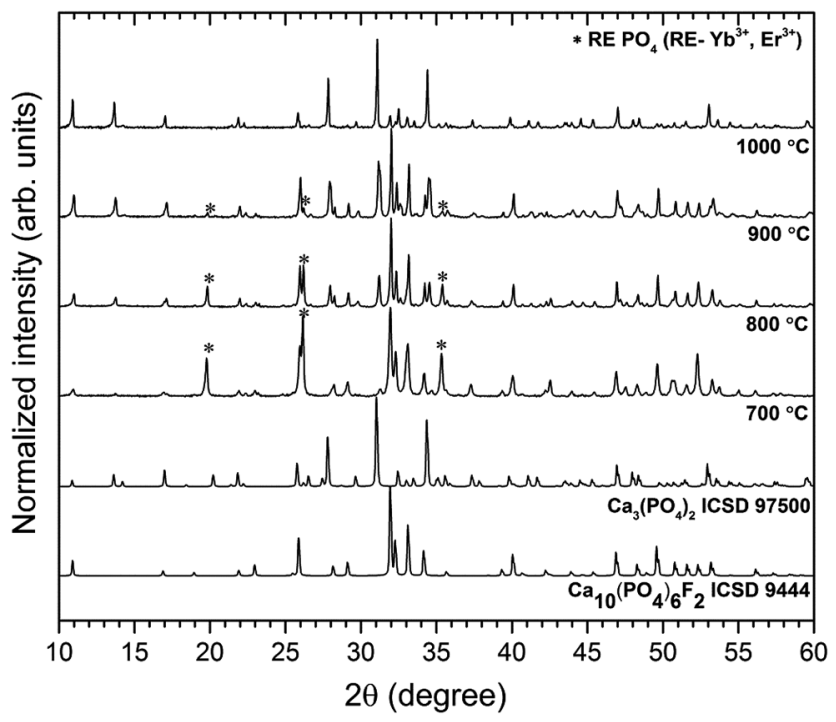

Fig. 1 Effect of annealing temperature on the structure evolution of the $\mathrm{Ca}_{10}\left(\mathrm{PO}_{4}\right)_{6} \mathrm{~F}_{2} / \mathrm{Ca}_{3}\left(\mathrm{PO}_{4}\right)_{2}$ co-doped with $1 \mathrm{~mol} \% \mathrm{Er}^{3+}$ and $5 \mathrm{~mol} \%$ $\mathrm{Yb}^{3+}$. obtained materials was noted by XRD analysis. However, the FAp and the $\beta$-TCP phases were observed at all annealing temperatures. Moreover, up to $900{ }^{\circ} \mathrm{C}$, the traces of the $\mathrm{REPO}_{4}$ (where $\mathrm{RE}-\mathrm{Er}^{3+}, \mathrm{Yb}^{3+}$ ) were identified, but these extra phases were not found at $1000{ }^{\circ} \mathrm{C}$. As can be seen, with the increase of temperature treatment, the amount of the FAp phase was reduced in favour of the $\beta$-TCP phase. At temperature of $1000{ }^{\circ} \mathrm{C}$, much more tricalcium phosphate was identified than fluorapatite in the biphasic calcium phosphate studied herein.

Since the goal of the studies was to obtain the $\mathrm{Ca}_{10}\left(\mathrm{PO}_{4}\right)_{6} \mathrm{~F}_{2} /$ $\mathrm{Ca}_{3}\left(\mathrm{PO}_{4}\right)_{2}$ nano-biphasic calcium phosphate, in accordance with the XRD analysis, for further characterization, the sample heat-treated at $1000{ }^{\circ} \mathrm{C}$ was chosen.

The $\beta$-tricalcium phosphate possesses five different $\mathrm{Ca}^{2+}$ crystallographic sites and the fluorapatite has two nonequivalent $\mathrm{Ca}^{2+}$ sites, $\mathrm{Ca}(1)$ coordinated by nine oxygen atoms and $\mathrm{Ca}(2)$ coordinated by six oxygen atoms and one fluoride ion. The ionic radii of $\mathrm{Er}^{3+}$ and $\mathrm{Yb}^{3+}$ cations are quite similar to calcium ion thereupon, it can be predicted that these cations will enter most of the $\mathrm{Ca}^{2+}$ sites in both the fluorapatite and the $\beta$-TCP host lattices.

The visualisation of the fluorapatite (up) and the $\beta$-tricalcium phosphate (bottom) unit cells and the coordination polyhedra of $\mathrm{Ca}^{2+}$ cations are presented in Fig. 2 .

The structural refinement was done by using the Maud program version $2.68^{\mathbf{4 0 , 4 1}}$ and based on the fluorapatite crystals with hexagonal structure and $\beta$-tricalcium phosphate crystal using a better approximation as well as indexing of the Crystallographic Information File (CIF). The quality of structural refinement was checked by $R$-values $\left(R_{\mathrm{w}}, R_{\mathrm{wnb}}, R_{\mathrm{all}}, R_{\mathrm{nb}}\right.$ and $\sigma$ ) since these numbers are easy to detect being consistent with a hexagonal structure of fluorapatite and a rhombohedral structure of tricalcium phosphate. Furthermore, a difference in plotting observed and calculated patterns is the best way to judge the success of Rietveld refinement. The parameters with additional functions were applied to find a structural refinement with better quality and reliability. The conformation of the hexagonal and the rhombohedral phase formation were affirmed by the obtained results. Fig. 3 shows a good agreement between the observed XRD pattern and the theoretical fit which indicates the validity of the Rietveld refinement method as illustrated by the small differences near to zero in the intensity scale in the line $\left(Y_{\text {Obs }}-Y_{\text {Calc }}\right)$. More details regarding Rietveld refinement are displayed in Table 1.

According to the HRTEM study, the primary size and morphology evaluation of the $1 \mathrm{~mol} \% \mathrm{Er}^{3+}, 5 \mathrm{~mol} \% \mathrm{Yb}^{3+}$ doped $\mathrm{Ca}_{10}\left(\mathrm{PO}_{4}\right)_{6} \mathrm{~F}_{2} / \mathrm{Ca}_{3}\left(\mathrm{PO}_{4}\right)_{2}$ particles were explored by means of transmission electron microscopy (TEM) and was found to be around $90 \mathrm{~nm}$ in the case of the $1000{ }^{\circ} \mathrm{C}$ temperature treatment (see Fig. 4). The spherical particles as well as agglomerated irregular grains were observed. The broad distribution of the primary size is characteristic of all materials where high temperature thermal treatment has been involved.

In accordance with analysis of the SAED (Selected Area Electron Diffraction) images (see Fig. $4 \mathrm{~b}$ and c) this points to the presence of well-developed spotty rings confirming a high level of material crystallization. Moreover, the obtained sample 

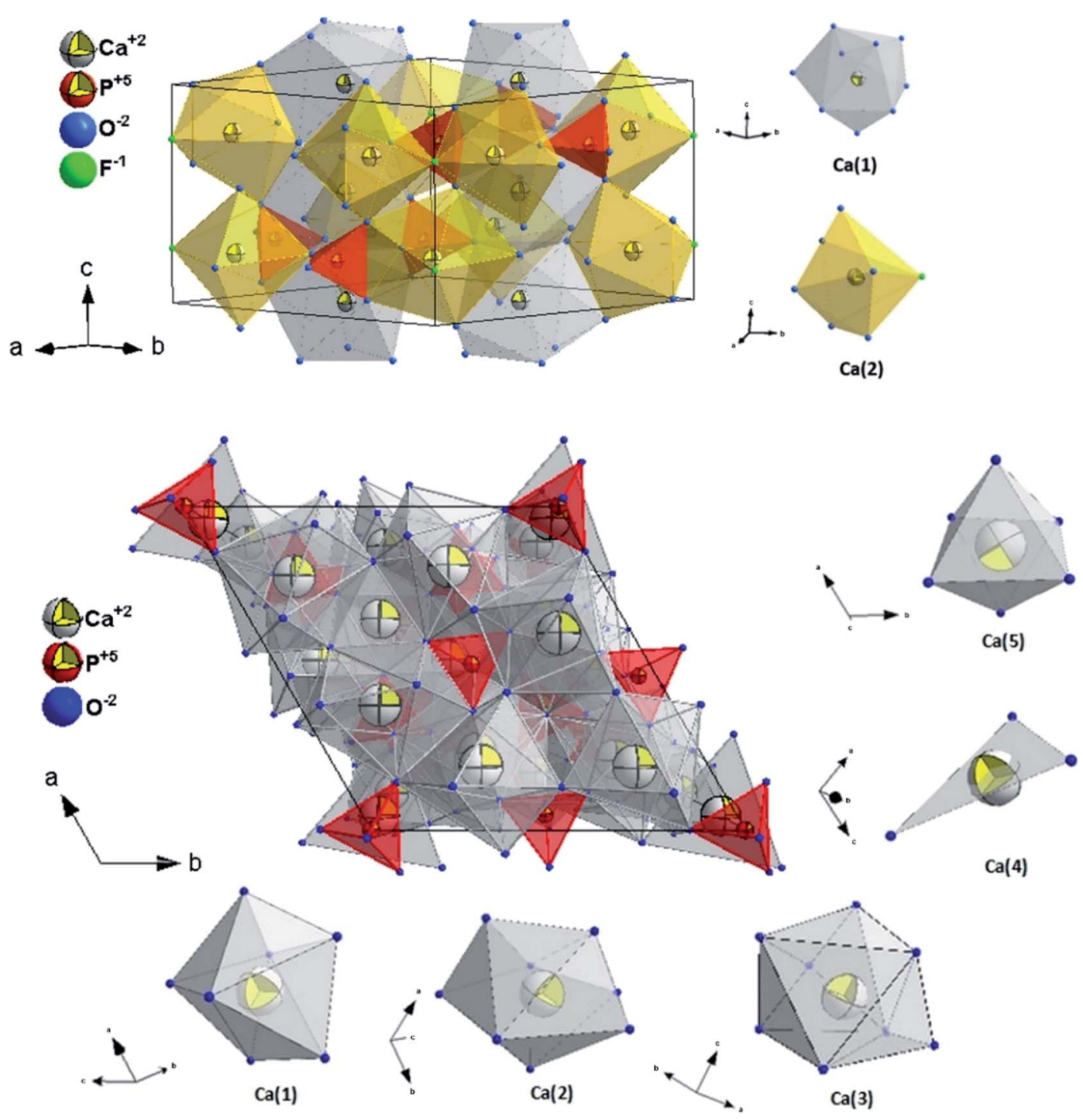

Fig. 2 The projection of the FAp (top) and $\beta$-TCP (bottom) unit cell with the indication of the coordination polyhedral.

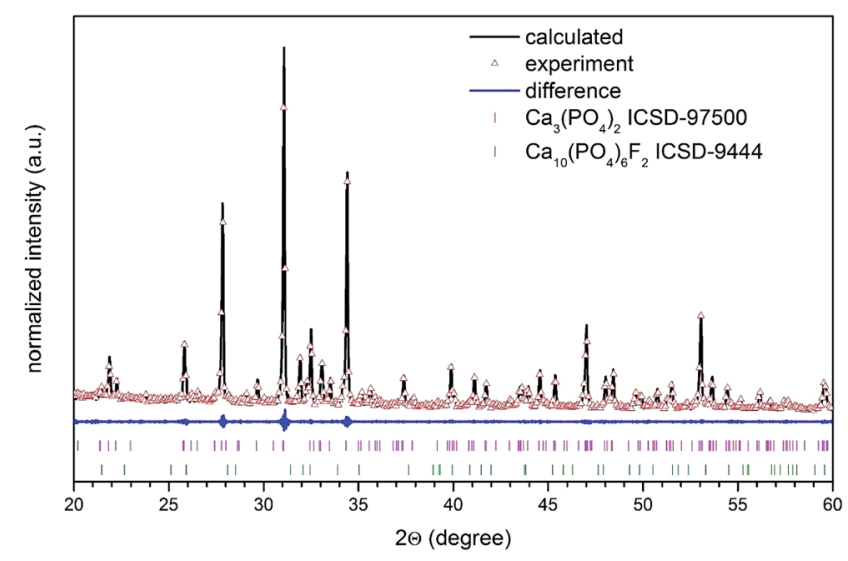

Fig. 3 The Rietveld analysis of the $\mathrm{Ca}_{10}\left(\mathrm{PO}_{4}\right)_{6} \mathrm{~F}_{2} / \mathrm{Ca}_{3}\left(\mathrm{PO}_{4}\right)_{2}$ biphasic calcium phosphate co-doped with 1 mol\% $\mathrm{Er}^{3+}$ and $5 \mathrm{~mol} \% \mathrm{Yb}^{3+}$ heated at $1000{ }^{\circ} \mathrm{C}$ (XRD pattern - black lines, red - fitted diffraction; blue - differential pattern; column - reference phase peak position). calcined at $1000{ }^{\circ} \mathrm{C}$ shows the SAED spots patterns with the clear diffraction patterns indicating strong development of rhombohedral $\mathrm{Ca}_{3}\left(\mathrm{PO}_{4}\right)_{2}$ (see Fig. 4b) and hexagonal $\mathrm{Ca}_{10}\left(\mathrm{PO}_{4}\right)_{6} \mathrm{~F}_{2}$ (see Fig. 4c) phases. These SAED analyses confirmed the formation of both structures and are in agreement with the XRD results.

In order to confirm the content of particular elements in the material, the EDX (Fig. 5) as well as ICP techniques were employed. The element maps were drawn up by the SEM-EDS measurement to check the incorporation regularity of the cations into the lattice (Fig. 6).

The results confirm the stoichiometric contents and regular substitution of cations in the material. The SEM-EDS analysis was performed for all samples to verify the content of fluorine ions. The process of defluoridation was observed depending on the annealing temperature (see Fig. 5). The fluorapatite component released fluoride during heat-treatment, particularly above $1000{ }^{\circ} \mathrm{C}$. This may be caused by removal of $\mathrm{NH}_{4} \mathrm{~F}$ compound due to its low decomposition temperature $\left(\sim 100^{\circ} \mathrm{C}\right)$. 
Table 1 Unit cell parameters ( $a$ and $c)$, crystal cell volume ( $V$, the number of phases (Ph) calculated according to the Rietveld methods, as well as refined factors $\left(R_{\mathrm{w}}\right)$ presented for $1 \mathrm{~mol} \% \mathrm{Er}^{3+}, 5 \mathrm{~mol} \% \mathrm{Yb}^{3+}: \mathrm{Ca}_{10}\left(\mathrm{PO}_{4}\right)_{6} \mathrm{~F}_{2} / \mathrm{Ca}_{3}\left(\mathrm{PO}_{4}\right)_{2}$ biphasic calcium phosphate

\begin{tabular}{|c|c|c|c|c|c|c|c|c|c|}
\hline \multirow[b]{3}{*}{ Sample } & \multicolumn{6}{|c|}{ Cell parameters } & \multicolumn{2}{|l|}{$\underline{\mathrm{Ph}}$} & \multirow[b]{3}{*}{$R_{\mathrm{w}}[\%]$} \\
\hline & \multicolumn{3}{|l|}{ FAp $^{42}$} & \multicolumn{3}{|l|}{$\beta-\mathrm{TCP}^{43}$} & \multirow[b]{2}{*}{ FAp [\%] } & \multirow[b]{2}{*}{$\beta$-ТСР $[\%]$} & \\
\hline & $a[\AA]$ & $c[\AA]$ & $V\left[\AA^{3}\right]$ & $a[\AA]$ & $c[\AA]$ & $V\left[\AA^{3}\right]$ & & & \\
\hline Single crystal & $9.363(2)$ & $6.878(2)$ & $522.18(22)$ & $10.4352(2)$ & $37.4029(5)$ & $3527.26(11)$ & - & - & - \\
\hline \multicolumn{10}{|c|}{$1 \mathrm{~mol} \% \mathrm{Er}^{3+} ; 5 \mathrm{~mol} \% \mathrm{Yb}^{3+}$} \\
\hline $1000^{\circ} \mathrm{C}$ & $9.3746(4)$ & $6.8796(2)$ & $523.60(56)$ & $10.4258(5)$ & $37.3607(5)$ & $3516.97(40)$ & 12.9 & 87.1 & 3.50 \\
\hline
\end{tabular}

Another reason for lower fluorine content could be connected with the removal of carbon dioxide, which exists in several forms depending on the temperature. Above $800^{\circ} \mathrm{C}$ it flies in the form of $\mathrm{CO}_{3} \mathrm{~F}^{20}$ Since the sample was prepared by the sol-gel method using a large amount of citric acid and ethylene glycol, there is plenty of carbon. Moreover, the sol-gel preparation showed the removal of fluorine ions from apatite materials. Such phenomenon could be valuable in the development of bioactive phosphates preparation for a controlling of the fluoride ion concentration, especially for dental managements. It is worth pointing out that excessive concentration of the fluoride ions could be toxic and leading to the dental fluorosis characterized by the hypo-mineralization of tooth enamel. ${ }^{11}$ Moreover, the fluoride ions used as a substitution in the hydroxyapatite improve its physicochemical properties thus promote osteoblastic activities in terms of cell proliferation and differentiation as well as bone mineralization. ${ }^{10}$ The fluoride ions doped hydroxyapatite prevent, reduce and control dental caries. ${ }^{44}$

\subsection{Optical properties}

The up-conversion emission can be observed in the systems composed of one type of ions i.e. $\mathrm{Er}^{3+}$ ions. However, due to the small absorption cross section of the $\mathrm{Er}^{3+}$ ions the use of additional strongly-absorbing resonant co-dopants such as the $\mathrm{Yb}^{3+}$ ions with a large absorption cross section can significantly influence on up-conversion emission process. The $\mathrm{Yb}^{3+}$ ion, socalled sensitizer, promotes the efficiency of energy transfer to the activator $-\mathrm{Er}^{3+}$ ion. ${ }^{34}$ In fact, the energy transfer is possible as the resonance effect between energy levels of both ions (the
${ }^{2} \mathrm{~F}_{5 / 2} \rightarrow{ }^{2} \mathrm{~F}_{7 / 2}\left(\mathrm{Yb}^{3+}\right)$ and $\left.{ }^{4} \mathrm{I}_{15 / 2} \rightarrow{ }^{4} \mathrm{I}_{11 / 2}\left(\mathrm{Er}^{3+}\right)\right)$. Additionally, significantly higher concentrations of the sensitizer relative to the activator promotes the occurrence of this process. The upconversion emission spectra of the $\mathrm{Ca}_{10}\left(\mathrm{PO}_{4}\right)_{6} \mathrm{~F}_{2} / \mathrm{Ca}_{3}\left(\mathrm{PO}_{4}\right)_{2}$ doped with $1 \mathrm{~mol} \% \mathrm{Er}^{3+}$ and $5 \mathrm{~mol} \% \mathrm{Yb}^{3+}$ ions heat treated at $1000{ }^{\circ} \mathrm{C}$ were measured at room temperature recording on continuous $980 \mathrm{~nm}$ under different laser diode power regimes (see Fig. 7). All the spectra were corrected according to instrument response.

The up-conversion emission transitions can be identified as a group of lines in the green spectral range of 520-575 nm (19 231-17 $391 \mathrm{~cm}^{-1}$ ) connected with the ${ }^{2} \mathrm{H}_{11 / 2} \rightarrow{ }^{4} \mathrm{I}_{15 / 2}$ and the ${ }^{4} \mathrm{~S}_{3 / 2} \rightarrow{ }^{4} \mathrm{I}_{15 / 2}$ electronic transitions, and in the red region of 635-700 nm (15 748-14 $\left.286 \mathrm{~cm}^{-1}\right)$, attributed to the ${ }^{4} \mathrm{~F}_{9 / 2} \rightarrow$ ${ }^{4} \mathrm{I}_{15 / 2}$ transition. These peaks are relatively broad and not resolved into particular Stark components. An occupation of different crystallographic sites by $\mathrm{Er}^{3+}$ and $\mathrm{Yb}^{3+}$ ions which thereupon create an overlap of emission lines from respective sites could be the reason for broadening of emission transitions.

Moreover, further reasons could explain such behaviour such as different oxidation states of dopants or structural defects, so-called charge compensation mechanisms and their heterogeneous distribution in nanomaterials as well as small particle size resulting into larger surface area. ${ }^{45,46}$ It is well known that the ${ }^{2} \mathrm{H}_{11 / 2} \rightarrow{ }^{4} \mathrm{I}_{15 / 2}$ transition changes drastically in comparison with ${ }^{4} \mathrm{~S}_{3 / 2} \rightarrow{ }^{4} \mathrm{I}_{15 / 2}$ under the dependence of laser power. This is related to the $\mathrm{Er}^{3+}$ ions as a temperature sensor in this spectral region. ${ }^{47}$ This could be confirmed by the streak camera images taken at $300 \mathrm{~K}$ as shown in Fig. 8 (left).

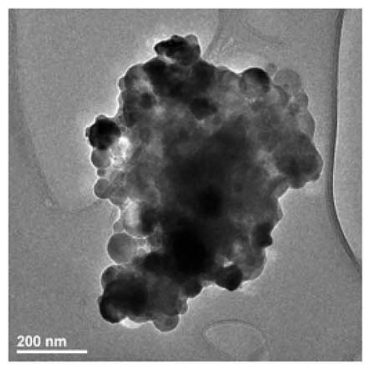

(a)

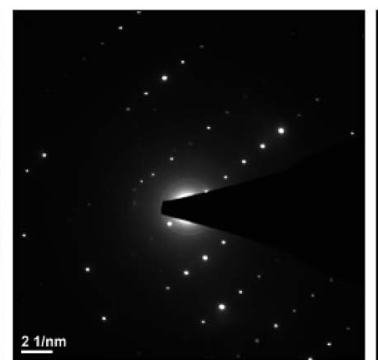

(b)

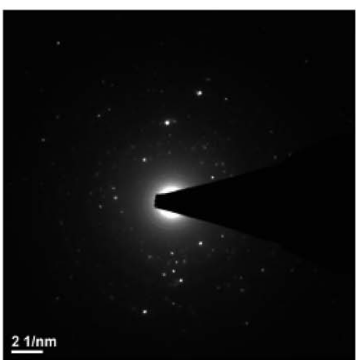

(c)

Fig. 4 (a) TEM and (b, c) SAED images of the $\mathrm{Ca}_{10}\left(\mathrm{PO}_{4}\right)_{6} \mathrm{~F}_{2} / \mathrm{Ca}_{3}\left(\mathrm{PO}_{4}\right)_{2}$ biphasic calcium phosphate doped with 1 mol\% $\mathrm{Er}^{3+}$ and 5 mol\% $\mathrm{Yb}^{3+}$ prepared at $1000^{\circ} \mathrm{C}$. 

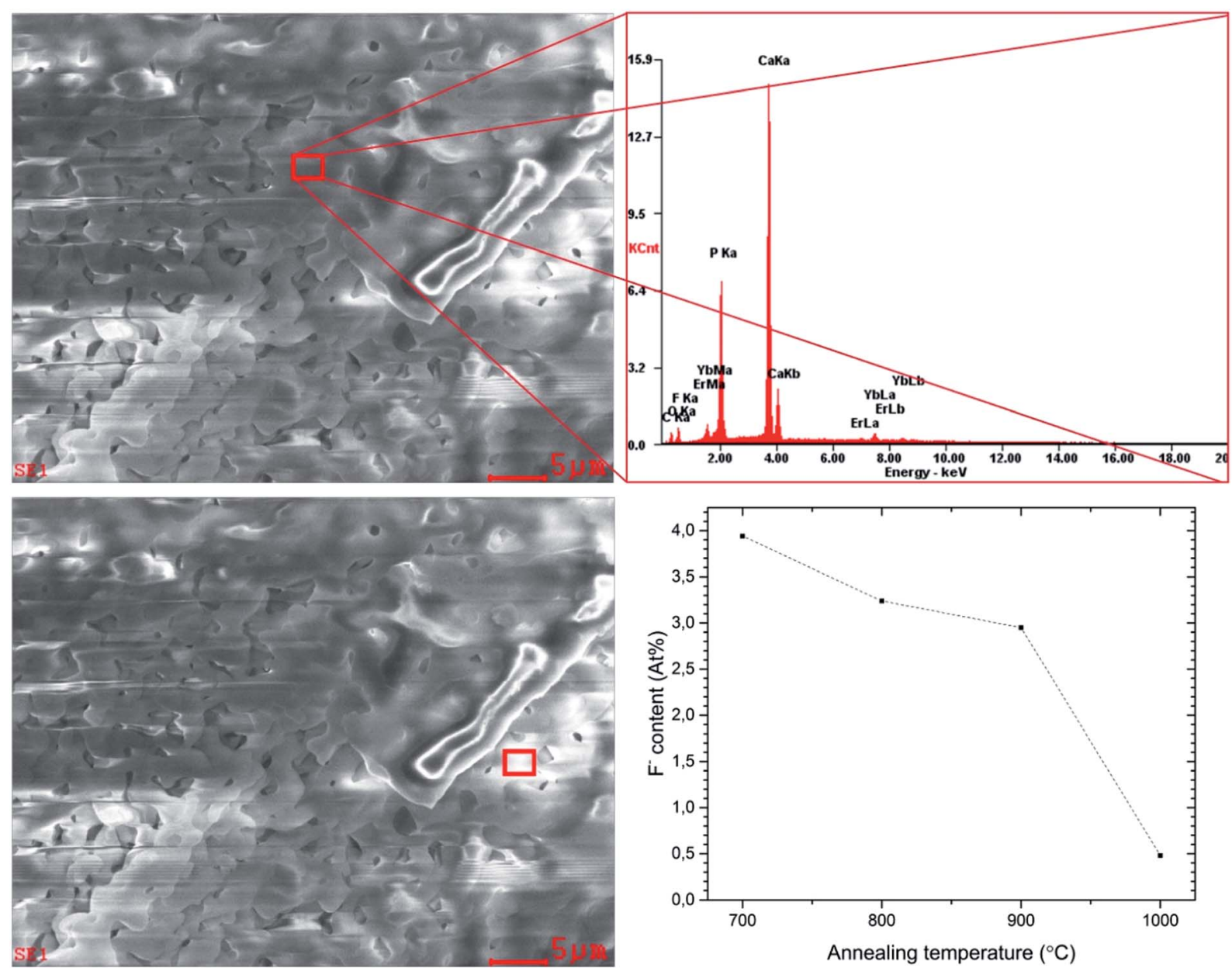

Fig. 5 EDX scans and spectrum of $\mathrm{Ca}_{10}\left(\mathrm{PO}_{4}\right)_{6} \mathrm{~F}_{2} / \mathrm{Ca}_{3}\left(\mathrm{PO}_{4}\right)_{2}$ biphasic calcium phosphate co-doped with 1 mol\% $\mathrm{Er}^{3+}$ and 5 mol\% Yb ${ }^{3+}$ annealed at $1000{ }^{\circ} \mathrm{C}$, measured at different powder locations and fluoride ion content vs. annealing temperature of the sample detected.

Moreover, it could be noted that the intensity of the green emission of $\mathrm{Er}^{3+}$ ions increased in relation to red emission with the increasing laser power. The analysis of the integrated intensity ratio between green and red transitions could be considered as an indirect method for estimating the efficiency of the up-conversion process (green-to-red ratio GRR) (see Fig. 8 (right)). The GRR ratio depends directly on occupied point symmetry and the closest surrounding of emitting ions in the crystal field as well as excitation power related to the thermal effects influencing population of electronic states.

Furthermore, it is noteworthy that laser power significantly affects the relative intensity of the ${ }^{2} \mathrm{H}_{11 / 2} \rightarrow{ }^{4} \mathrm{I}_{15 / 2}$ and the ${ }^{4} \mathrm{~S}_{3 / 2}$ $\rightarrow{ }^{4} \mathrm{I}_{15 / 2}$ causing self-heating of the sample. This is related to the Boltzmann's distribution populated by both overlapping energy levels:

$$
\begin{aligned}
\mathrm{FIR} & =\frac{I\left({ }^{2} \mathrm{H}_{11 / 2} \rightarrow{ }^{4} \mathrm{I}_{15 / 2}\right)}{I\left({ }^{4} \mathrm{~S}_{3 / 2} \rightarrow{ }^{4} \mathrm{I}_{15 / 2}\right)}=\frac{g_{\mathrm{H}} A_{\mathrm{H}} h \nu_{\mathrm{H}}}{g_{\mathrm{S}} A_{\mathrm{S}} h \nu_{\mathrm{S}}} \exp \left(-\frac{\Delta E}{k T}\right) \\
& =B \exp \left(-\frac{\Delta E}{k T}\right)
\end{aligned}
$$

where $g_{\mathrm{H}}$ and $g_{\mathrm{S}}$ are the degeneracy of the ${ }^{2} \mathrm{H}_{11 / 2}$ and ${ }^{4} \mathrm{~S}_{3 / 2}$ levels, $A_{\mathrm{H}}, A_{\mathrm{S}}$ and $\nu_{\mathrm{H}}, \nu_{\mathrm{S}}$ are the spontaneous emission rates and frequencies of the ${ }^{2} \mathrm{H}_{11 / 2} \rightarrow{ }^{4} \mathrm{I}_{15 / 2}$ and the ${ }^{4} \mathrm{~S}_{3 / 2} \rightarrow{ }^{4} \mathrm{I}_{15 / 2}$ transitions, $h$ is the Planck's constant, $k$ is the Boltzmann's constant, $T$ is absolute temperature and $\Delta E$ is the energy gap. ${ }^{4}$

The pump power dependence of both ${ }^{2} \mathrm{H}_{11 / 2},{ }^{4} \mathrm{~S}_{3 / 2} \rightarrow{ }^{4} \mathrm{I}_{15 / 2}$ and ${ }^{4} \mathrm{~F}_{9 / 2} \rightarrow{ }^{4} \mathrm{I}_{15 / 2}$ transitions were investigated for the $\mathrm{Ca}_{10}\left(\mathrm{PO}_{4}\right)_{6} \mathrm{~F}_{2} / \mathrm{Ca}_{3}\left(\mathrm{PO}_{4}\right)_{2}$ biphasic calcium phosphate co-doped with $1 \mathrm{~mol} \% \mathrm{Er}^{3+}$ and $5 \mathrm{~mol} \% \mathrm{Yb}^{3+}$ prepared at $1000{ }^{\circ} \mathrm{C}$ (see Fig. 9). The up-conversion emission results were fitted giving slope values of the linear function around 1 (1.4) for the red band and close to 2 (1.9) for the green band confirming the involvement of 2 photons in green emission. It was observed an increase in the GRR with LD power due to the higher population of ${ }^{2} \mathrm{H}_{11 / 2} \rightarrow{ }^{4} \mathrm{I}_{15 / 2}$ (so-called thermalization process).

The spectral behavior of the UC processes as well as the dynamics of the signal indicate that involving $\mathrm{Er}^{3+}$ and $\mathrm{Yb}^{3+}$ ions is the mechanism for emissions at 523, 548 and $665 \mathrm{~nm}$.

In the literature, three mechanisms for the up-conversion emission were proposed: the APTE effect called ETU (energy transfer up-conversion), excited state absorption (ESA) and photon avalanche (PA). Moreover, it is difficult to distinguish these processes directly due to the quadratic power dependence. 

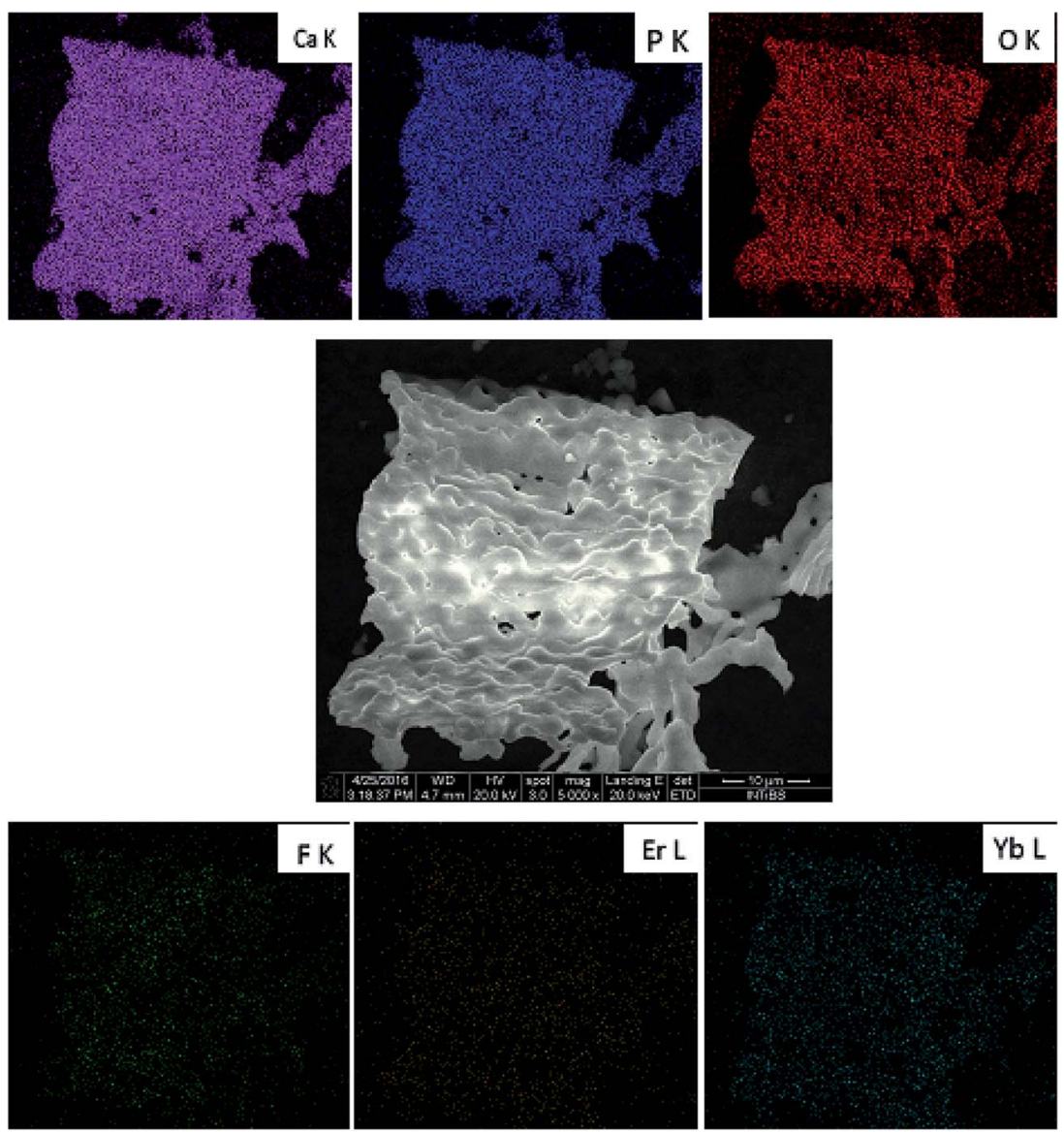

Fig. 6 SEM-EDS elemental maps of the $\mathrm{Ca}_{10}\left(\mathrm{PO}_{4}\right)_{6} \mathrm{~F}_{2} / \mathrm{Ca}_{3}\left(\mathrm{PO}_{4}\right)_{2}$ biphasic calcium phosphate co-doped with $1 \mathrm{~mol}^{2} \mathrm{Er}^{3+}$ and 5 mol\% $\mathrm{Yb}^{3+}$ prepared at $1000^{\circ} \mathrm{C}$.

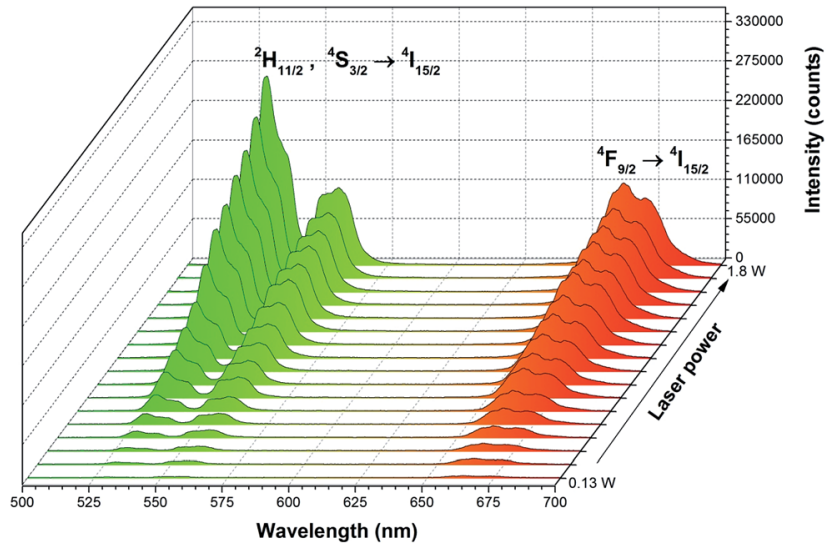

Fig. 7 Up-conversion emission spectra of the $\mathrm{Ca}_{10}\left(\mathrm{PO}_{4}\right)_{6} \mathrm{~F}_{2} / \mathrm{Ca}_{3}\left(\mathrm{PO}_{4}\right)_{2}$ biphasic calcium phosphate doped with $1 \mathrm{~mol} \% \mathrm{Er}^{3+}$ and $5 \mathrm{~mol} \% \mathrm{Yb}^{3+}$ annealed at $1000^{\circ} \mathrm{C}$ as a function of laser diode (LD) power at $980 \mathrm{~nm}$

The schematic and simplified energy level diagram presenting the most important accompanying and contributing processes to the up-conversion emission in the $\mathrm{Er}^{3+}$ and $\mathrm{Yb}^{3+}$ ions co-doped $\mathrm{Ca}_{10}\left(\mathrm{PO}_{4}\right)_{6} \mathrm{~F}_{2} / \mathrm{Ca}_{3}\left(\mathrm{PO}_{4}\right)_{2}$ (see Fig. 10). The NIR absorption of photons through the $\mathrm{Yb}^{3+}$ and $\mathrm{Er}^{3+}$ electrons directly from the ground states ${ }^{2} \mathrm{~F}_{7 / 2}$ and ${ }^{4} \mathrm{I}_{15 / 2}$ are excited to the ${ }^{2} \mathrm{~F}_{5 / 2}$ and ${ }^{4} \mathrm{I}_{11 / 2}$ levels by GSA processes. First, the absorbed photon shifted electrons were formed from ${ }^{4} \mathrm{I}_{11 / 2}$ level to the ${ }^{4} \mathrm{~F}_{7 / 2}$ by excited state absorption (ESA). Next, the energy was absorbed by $\mathrm{Yb}^{3+}$ ions and the electrons could be moved simultaneously to the ${ }^{4} \mathrm{~F}_{7 / 2}$ level of $\mathrm{Er}^{3+}$ ion by ETU (energy transfer up-conversion) as well as the ${ }^{4} \mathrm{I}_{11 / 2}$ level of the $\mathrm{Er}^{3+}$ ion by ET (energy transfer) processes. These processes require the participation of at least two photons. After that, the electrons from the ${ }^{4} \mathrm{~F}_{7 / 2}$ level relaxed very fast nonradiatively to the ${ }^{2} \mathrm{H}_{11 / 2}$ and ${ }^{4} \mathrm{~S}_{3 / 2}$ levels through multiphonon relaxation process (MPR) or farther to ${ }^{4} \mathrm{~F}_{9 / 2}$ level by cross relaxation (CR) and beyond these levels, green or red emission may occur up to the ${ }^{4} \mathrm{I}_{15 / 2}$ ground state. The CR depends on the ion concentration in the matrix as well and is sensitive to laser-power. Several highly probable processes of the CR may occur:
(1) CR1: $\left({ }^{4} \mathrm{~F}_{9 / 2}\right) \rightarrow\left({ }^{4} \mathrm{~S}_{3 / 2},{ }^{4} \mathrm{I}_{9 / 2}\right)$;
(2) CR2: $\left({ }^{4} \mathrm{~F}_{9 / 2}\right) \rightarrow\left({ }^{4} \mathrm{~F}_{7 / 2},{ }^{4} \mathrm{I}_{11 / 2}\right)$;
(3) CR3: $\left({ }^{4} \mathrm{I}_{9 / 2}\right) \rightarrow\left({ }^{4} \mathrm{~S}_{3 / 2},{ }^{4} \mathrm{I}_{13 / 2}\right)$. 

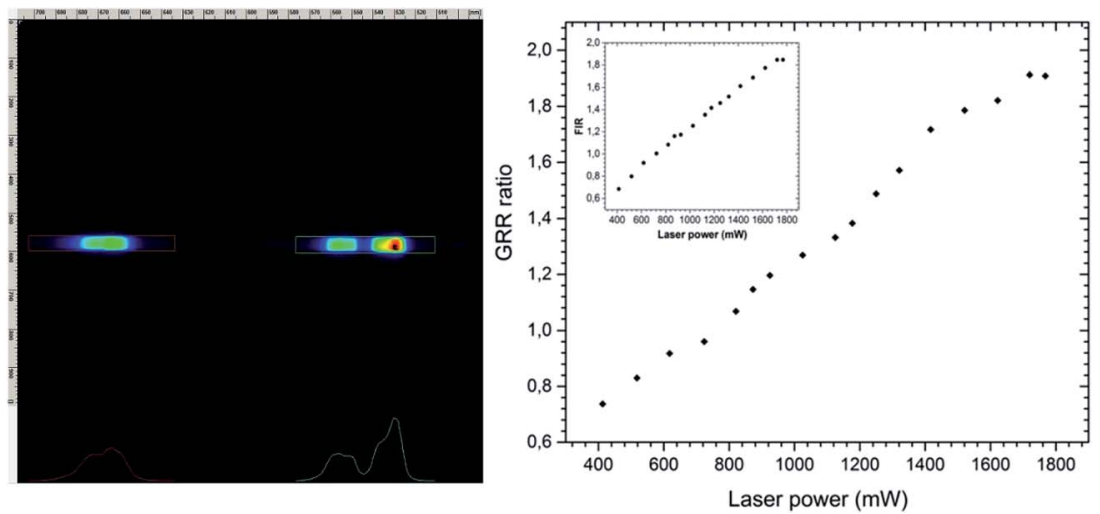

Fig. 8 Up-conversion streak camera image (left) and GRR ratio (right) together with FIR power dependence (inset) of the $\mathrm{Ca}_{10}\left(\mathrm{PO}_{4}\right)_{6} \mathrm{~F}_{2} / \mathrm{Ca}_{3}\left(\mathrm{PO}_{4}\right)_{2}$ biphasic calcium phosphate co-doped with $1 \mathrm{~mol} \% \mathrm{Er}^{3+}$ and $5 \mathrm{~mol} \% \mathrm{Yb}^{3+}$ prepared at $1000^{\circ} \mathrm{C}$.

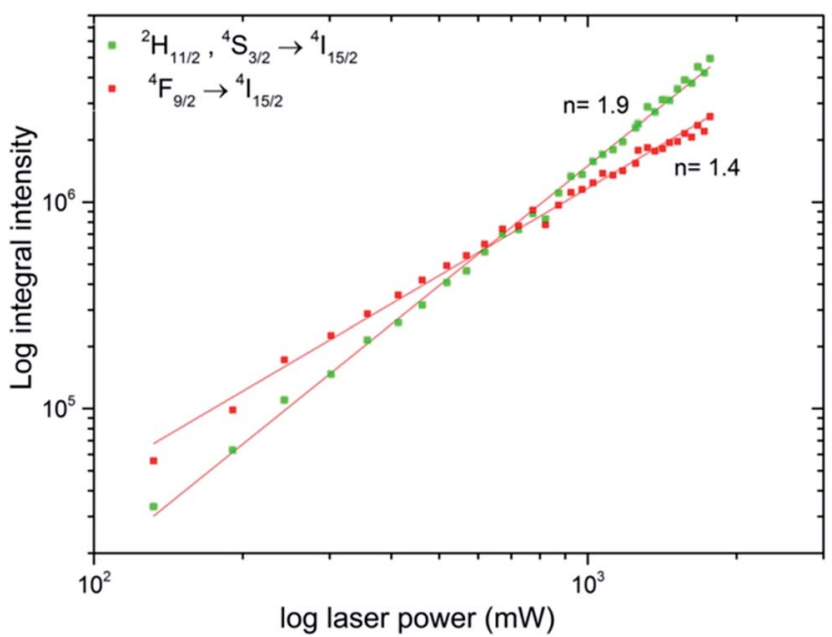

Fig. 9 Power dependence of the $\mathrm{Ca}_{10}\left(\mathrm{PO}_{4}\right)_{6} \mathrm{~F}_{2} / \mathrm{Ca}_{3}\left(\mathrm{PO}_{4}\right)_{2}$ biphasic calcium phosphate co-doped with $1 \mathrm{~mol} \% \mathrm{Er}^{3+}$ and $5 \mathrm{~mol} \% \mathrm{Yb}^{3+}$ prepared at $1000^{\circ} \mathrm{C}$.

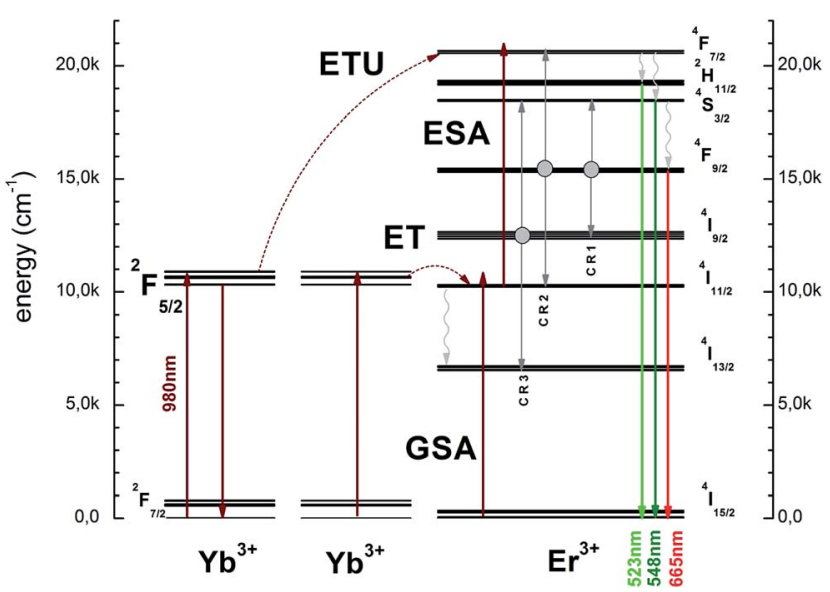

Fig. 10 Simplified energy level scheme presenting up-conversion the $\mathrm{Ca}_{10}\left(\mathrm{PO}_{4}\right)_{6} \mathrm{~F}_{2} / \mathrm{Ca}_{3}\left(\mathrm{PO}_{4}\right)_{2}$ biphasic calcium phosphate.
It can be noticed that the efficiency of the up-conversion process between $\mathrm{Yb}^{3+}$ and $\mathrm{Er}^{3+}$ ions located in biphasic phosphate was demonstrated with the increase of excitation power. A strong power dependence of the green and red emissions was found to be a result of temperature increase of nano-biphasic phosphate which show the potential prospect of that kind of ceramic in temperature-sensing applications. The luminescence nanothermometry exploits the relation between temperature and luminescence properties to achieve thermal sensing from the spectral analysis of the measured material. In case of $\mathrm{Er}^{3+}$ and $\mathrm{Yb}^{3+}$ pairs of ions it is possible to monitor the temperature of the particle by analyzing the emission spectra due to the ${ }^{4} \mathrm{~S}_{3 / 2}$ state is a metastable and the population of ${ }^{2} \mathrm{H}_{11 / 2}$ increases via its Boltzmann population (see eqn (4)). The relation between that states is shown as FIR power dependence (see Fig. 8, inset) which presents how using the relative emission intensity can determine the temperature of the nanocrystal. That phenomenon makes the $\mathrm{Ca}_{10}\left(\mathrm{PO}_{4}\right)_{6} \mathrm{~F}_{2} / \mathrm{Ca}_{3}\left(\mathrm{PO}_{4}\right)_{2}: \mathrm{Er}^{3+}, \mathrm{Yb}^{3+}$ an attractive composite for use in nanothermometry.

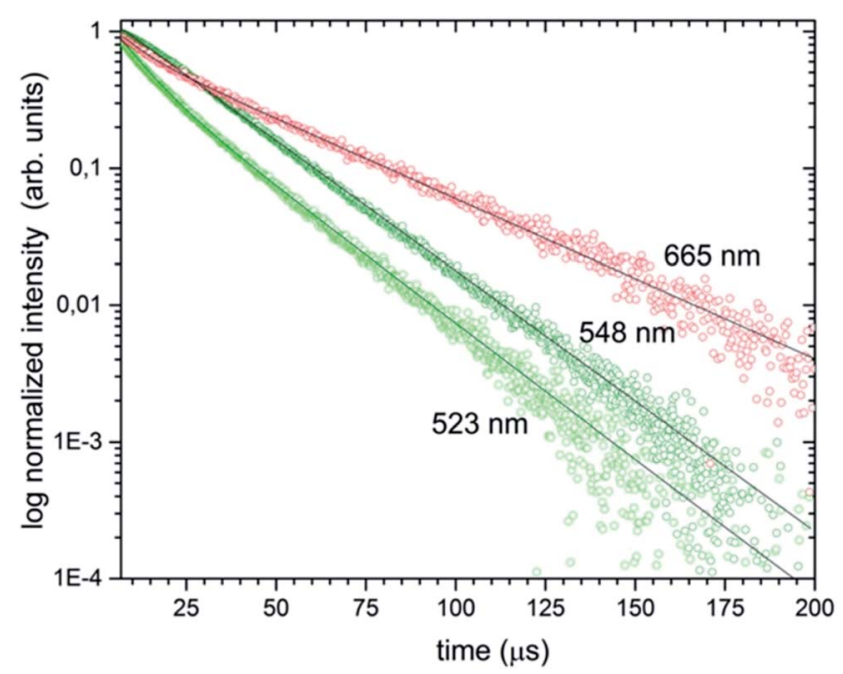

Fig. 11 Luminescence decay curves of the $\mathrm{Ca}_{10}\left(\mathrm{PO}_{4}\right)_{6} \mathrm{~F}_{2} / \mathrm{Ca}_{3}\left(\mathrm{PO}_{4}\right)_{2}$ biphasic calcium phosphate co-doped with $1 \mathrm{~mol} \% \mathrm{Er}^{3+}$ and $5 \mathrm{~mol} \%$ $\mathrm{Yb}^{3+}$ prepared at $1000^{\circ} \mathrm{C}$, under pulsed laser excitation at $980 \mathrm{~nm}$. 
The luminescence decays of the green and red emissions showed a double-exponential character and exhibited long (37.06-21.81 $\mu \mathrm{s})$ and short (6.46-8.12 $\mu \mathrm{s})$ components, suggesting the presence of more than one emitting centre (see Fig. 11). The double-exponential behaviour may be explained by various possible mechanisms. First of all, it could be related to the effects on particle surfaces. The ions located close to the surface are exposed to changes in the local environment and exhibit shorter luminescence times than these closer to particle cores with/displaying longer luminescence decays. Moreover, the dopant could be located in two different phases of the obtained sample which showed a significant contribution of the $\beta$ $\mathrm{TCP}$ phase at $1000^{\circ} \mathrm{C}$. In fact, in many up-converting materials, the radiative decay times of both green and red transitions are usually a few hundred microseconds in low concentrated samples and dozens of microseconds in highly concentrated samples.

\section{Conclusions}

The up-converting $\mathrm{Ca}_{10}\left(\mathrm{PO}_{4}\right)_{6} \mathrm{~F}_{2} / \mathrm{Ca}_{3}\left(\mathrm{PO}_{4}\right)_{2}$ biphasic calcium phosphate co-doped with $\mathrm{Er}^{3+}$ and $\mathrm{Yb}^{3+}$ ion-pairs was successfully fabricated using Pechini's technique. The preparation using these methods showed the removal of fluorine ions from the apatite phase. The process of defluoridation was observed to be dependent on the annealing temperature. The primary size of particles was evaluated at around $90 \mathrm{~nm}$ in the case of $1000{ }^{\circ} \mathrm{C}$ temperature treatment.

A biphasic calcium phosphate has been chosen as a material for implantology to improve dissolution characteristics imparted by the addition of $\beta$-tricalcium phosphate. The $\beta$ TCP phase undergoes faster resorption than FAp, allowing the precipitation of apatites. The choice of fluorapatite is reasonable due to more thermally stable and higher crystallinity than hydroxyapatite, what is also significant in cement production for implantology. The $\mathrm{Ca}_{10}\left(\mathrm{PO}_{4}\right)_{6} \mathrm{~F}_{2}$ and $\mathrm{Ca}_{3}\left(\mathrm{PO}_{4}\right)_{2}$ materials from different stable phases and the bioactivity as well as biodegradation of a biphasic phosphate containing both phases depends strongly on the variation of the ratio of FAp/ $\beta$-TCP.

It has been shown that the interplay of the intensity between transitions of the ${ }^{2} \mathrm{H}_{11 / 2} \rightarrow{ }^{4} \mathrm{I}_{15 / 2}$ and the ${ }^{4} \mathrm{~S}_{3 / 2} \rightarrow{ }^{4} \mathrm{I}_{15 / 2}$ changes during sample heating induced by different laser power levels suggesting possible applications of this material in nanothermometry. The analysis of the GRR ratio showed that increasing the GRR with laser power was attributed to the thermalization process resulting in a higher population of the ${ }^{2} \mathrm{H}_{11 / 2} \rightarrow{ }^{4} \mathrm{I}_{15 / 2}$ transition.

The luminescence decays were double-exponential and exhibited short and long decay components. The double exponential behavior is related by the presence of surface effects where the $\mathrm{Er}^{3+}$ ions are located at the surface and are more sensitive to the local environment as well as exhibit longer luminescence lifetimes. Moreover, the dopants are located in two different phases of the obtained sample with a significant contribution of the $\beta$-TCP phase.

\section{Acknowledgements}

The authors would like to thank M.Sc. Ewa Bukowska for performing XRD measurements, Ph.D. Malgorzata Malecka for TEM measurements. Financial support from the National Science Centre throughout the realization of the project 'Nanomaterials for fluorescence lifetimes bio-imaging (NFLBio)' (no. UMO-2012/06/M/ST5/00048) is gratefully acknowledged.

\section{References}

1 V. Stanić, A. S. Radosavljević-Mihajlović, V. ŽivkovićRadovanović, B. Nastasijević, M. Marinović-Cincović, J. P. Marković and M. D. Budimir, Appl. Surf. Sci., 2015, 337, 72-80.

2 F. Chen, P. Huang, Y.-J. Zhu, J. Wu and D.-X. Cui, Biomaterials, 2012, 33, 6447-6455.

3 T. Terukina, H. Saito, Y. Tomita, Y. Hattori and M. Otsuka, J. Drug Delivery Sci. Technol., 2017, 37, 74-80.

4 S. S. Banerjee, S. Tarafder, N. M. Davies, A. Bandyopadhyay and S. Bose, Acta Biomater., 2010, 6, 4167-4174.

5 M. Kheradmandfard, M. H. Fathi, F. Ansari and T. Ahmadi, Mater. Sci. Eng., C, 2016, 68, 136-142.

6 H. Qu and M. Wei, Acta Biomater., 2006, 2, 113-119.

7 N. Senamaud, D. Bemache-Assollant, E. Champion, M. Heughebaert and C. Rey, Solid State Ionics, 1997, 101103, 1357-1362.

8 N. Bouslama, B. F. Ayed and J. Bouaziz, Ceram. Int., 2009, 35, 1909-1917.

9 N. Iqbal, M. R. Abdul Kadir, N. H. Bin Mahmood, S. Iqbal, D. Almasi, F. Naghizadeh, H. R. Balaji and T. Kamarul, Ceram. Int., 2015, 41, 6470-6477.

10 A. Bianco, I. Cacciotti, M. Lombardi, L. Montanaro, E. Bemporad and M. Sebastiani, Ceram. Int., 2010, 36, 313322.

11 M. Jiménez-Reyes and M. Solache-Ríos, J. Hazard. Mater., 2010, 180, 297-302.

12 V. Stanić, S. Dimitrijević, D. G. Antonović, B. M. Jokić, S. P. Zec, S. T. Tanasković and S. Raičević, Appl. Surf. Sci., 2014, 290, 346-352.

13 J. Wei, J. Wang, X. Liu, J. Ma, C. Liu, J. Fang and S. Wei, Appl. Surf. Sci., 2011, 257, 7887-7892.

14 A. Escudero, M. E. Calvo, S. Rivera-Fernández, J. M. De La Fuente and M. Ocaña, Langmuir, 2013, 29, 1985-1994.

15 M. Nabiyouni, H. Zhou, T. J. F. Luchini and S. B. Bhaduri, Mater. Sci. Eng., C, 2014, 37, 363-368.

16 M. Karbowiak and S. Hubert, J. Alloys Compd., 2000, 302, 8793.

17 J. Akiyama, Y. Sato and T. Taira, Appl. Phys. Express, 2011, 4, 22703.

18 A. O. Wright, M. D. Seltzer, J. B. Gruber, B. Zandi, L. D. Merkle and B. H. T. Chai, J. Phys. Chem. Solids, 1996, 57, 1337-1350.

19 X. Hu, J. Zhu, X. Li, X. Zhang, Q. Meng, L. Yuan, J. Zhang, X. Fu, X. Duan, H. Chen and Y. Ao, Biomaterials, 2015, 52, 441-451. 
20 K. Tõnsuaadu, K. A. Gross, L. Pluduma and M. Veiderma, J. Therm. Anal. Calorim., 2012, 110, 647-659.

21 F. Ben Ayed and J. Bouaziz, Ceram. Int., 2008, 34, 1885-1892.

22 S. Kannan, F. Goetz-Neunhoeffer, J. Neubauer and J. M. F. Ferreira, J. Am. Ceram. Soc., 2008, 91, 1-12.

23 Y. Huang, C. Jiang, Y. Cao, L. Shi and H. J. Seo, Mater. Res. Bull., 2009, 44, 793-798.

24 R. Sahoo, S. K. Bhattacharya and R. Debnath, J. Solid State Chem., 2003, 175, 218-225.

25 R. K. Singh and S. Kannan, Mater. Sci. Eng., C, 2014, 45, 530538.

26 U. Meyer, U. Joos and H. P. Wiesmann, Int. J. Oral Maxillofac. Surg., 2004, 33, 635-641.

27 A. I. Orlova, S. N. Pleskova, N. V Malanina, A. N. Shushunov, E. N. Gorshkova, E. E. Pudovkina and O. N. Gorshkov, Inorg. Mater., 2013, 49, 696-700.

28 X. Zhang, L. Zhou and M. Gong, Opt. Mater., 2013, 35, 993997.

29 W. Zhou, J. Han, X. Zhang, Z. Qiu, Q. Xie, H. Liang, S. Lian and J. Wang, Opt. Mater., 2015, 39, 173-177.

30 I. M. Nagpure, S. S. Pitale, E. Coetsee, O. M. Ntwaeaborwa, J. J. Terblans and H. C. Swart, Opt. Mater., 2012, 34, 13981405.

31 I. M. Nagpure, S. Saha and S. J. Dhoble, J. Lumin., 2009, 129, 898-905.

32 A. Lecointre, A. Bessière, B. Viana, R. Aït Benhamou and D. Gourier, Radiat. Meas., 2010, 45, 273-276.

33 G. Chen, T. Y. Ohulchanskyy, S. Liu, W. C. Law, F. Wu, M. T. Swihart, H. Ågren and P. N. Prasad, ACS Nano, 2012, 6, 2969-2977.

34 M. Haase and H. Schafer, Angew. Chem., Int. Ed., 2011, 50, 5808-5829.
35 F. Cheng, K. Sun, Y. Zhao, Y. Liang, Q. Xin and X. Sun, Ceram. Int., 2014, 40, 11329-11334.

36 C. L. Tisdel, V. M. Goldberg, J. A. Parr, J. S. Bensusan, L. S. Staikoff and S. Stevenson, J. Bone Jt. Surg., 1994, 76, 159-171.

37 S. Overgaard, M. Lind, K. Josephsen, A. B. Maunsbach, C. Bünger and K. Søballe, J. Biomed. Mater. Res., 1998, 39, 141-152.

38 K. Marycz, P. Sobierajska, A. Smieszek, M. Maredziak, K. Wiglusz and R. J. Wiglusz, Mater. Sci. Eng., C, 2017, 78, 151-162.

39 K. Marycz, R. Pazik, K. Zawisza, K. Wiglusz, M. Maredziak, P. Sobierajska and R. J. Wiglusz, Mater. Sci. Eng., C, 2016, 69, 17-26.

40 H. M. Rietveld, J. Appl. Crystallogr., 1969, 2, 65-71.

41 L. Lutterotti, S. Matthies and H. R. Wenk, IUCr Newsletter, 1999, 21, 14-15.

42 K. Sudarsanan, P. E. Mackie and R. A. Young, Mater. Res. Bull., 1972, 7, 1331-1338.

43 M. Yashima, A. Sakai, T. Kamiyama and A. Hoshikawa, J. Solid State Chem., 2003, 175, 272-277.

44 E. Bertoni, A. Bigi, G. Cojazzi, M. Gandolfi, S. Panzavolta and N. Roveri, J. Inorg. Biochem., 1998, 72, 29-35.

45 P. Sobierajska, R. Pazik, K. Zawisza, G. Renaudin, J.-M. Nedelec and R. J. Wiglusz, CrystEngComm, 2016, 18, 3447-3455.

46 R. J. Wiglusz, B. Pozniak, K. Zawisza and R. Pazik, RSC Adv., 2015, 5, 27610-27622.

47 Y. Tian, B. Tian, C. Cui, P. Huang, L. Wang and B. Chen, RSC Adv., 2015, 5, 14123-14128. 